\title{
Role of Employee Engagement on \\ Compensation System and Employee Performance Relationship among Telecommunication Service Providers in Bangladesh
}

\author{
Abu Shams Mohammad Mahmudul Hoque \\ Faculty of Economics and Management Sciences, Universiti Sultan Zainal Abidin (UniSZA), \\ Terengganu, Malaysia \\ Zainudin Bin Awang \\ Faculty of Economics and Management Sciences, Universiti Sultan Zainal Abidin (UniSZA), \\ Terengganu, Malaysia
}

Benazir Ahmed Siddiqui

School of Business Management, Universiti Utara Malaysia,

Sintok, Malaysia

Malam Salihu Sabiu

Department of Public Admin, Umaru Ali Shinkafi Polytechnic,

Sokoto, Nigeria

Received: April 30, 2018 Accepted: May 17, 2018 Online published: May 18, 2018

doi:10.5296/ijhrs.v8i3.13081ＵRL: https://doi.org/10.5296/ijhrs.v8i3.13081

\begin{abstract}
Past studies endorsed that there is a quite number of factors have been considered as the influencing factors of employee performance in an organization. Some of these are selection, training and development, performance appraisal, promotion, job design, security, and
\end{abstract}


satisfaction, compensation system, employee commitment, personality, emotional intelligence, organizational citizenship behavior among others. While several studies considered investigating the influence of human resource management practices on employee performance in different context such as America, Africa and Europe, but very little attention have given in South-Asian countries like Bangladesh. Hence, this manuscript attempted to investigate the impact of compensation system on employee performance using quantitative analysis. To do so, survey was conducted as well as perceptions of 200 employees working in telecommunication service providers in Bangladesh were obtained to analyze the relationships. The data is analyzed and hypotheses were tested by using IBM-SPSS-AMOS package 25.0. The study found that employee engagement partially mediates the relationship between compensation system and employee performance by the data of this study. This research indorsed that there is a candid need to implement better compensation system by the entrepreneurs which will ensure better employee performance in line with consistent growth of firms as well as Bangladeshi GDP.

Keywords: employee performance, compensation system, employee engagement

\section{Introduction}

Generally, performance is an important aspect of development for both employees and the organization or firm (Hoque, Awang, and Salam, 2017a; Hoque \& Awang, 2016a). Hence, there is a need to understand the basic concept of performance in the discussion of employee performance concept. Performance can simply be explained as the aptitude to produce results, in relation to an objective (Laitinen, 2009). Similarly, Andersen (2010) argued from the economic perspectives that performance focus on efficiency and effectiveness of the firm in handling their cost and outcomes, while process perspective performance emphasizes on transformation from inputs to outputs in order to achieve definite results (Abu Jarad, Yusof, \& Wira Mohd Shafiei, 2010; Chen Lee, Hou, Chen, Hsu, and Jin, 2004).

Whereas, Muchinsky (2003), employee performance (EP) can be seen as a set of employee's behaviors that can be observed, assess and measure success at the individual level. EP should be regarded as actions and behaviors of employees rather than outcomes yielded by the employees (Cardy \& Selvarajan, 2004; Muchinsky, 2003). However, scholars like Viswesvaran \& Ones (2000) mentioned that separating between behaviors and outcomes might be very difficult, henceforth, the need to include the result in conceptualizing EP. As a whole, EP has been seen as mountable behavior, activities and results that engage workers in relation to gain organizational goals and objectives (Viswesvaran \& Ones, 2000).

According to Chen, Eberly, Chiang, Farh, \& Cheng, (2014); Tsui, Lin, \& Yu, (2013); Cekmecelioglu \& Gunsel, (2011), Arshadi, (2010); Abbas \& Yaqoob, (2009), numerous factors have been studied as influencing factors of EP in organization. However, Azhdar, Samira, \& Sarani (2015); Obi-Anike \& Ekwe (2014); Trehan, \& Setia (2014), mentioned that among the influencing factors, compensation system (CS) has significant influence on EP. According to Islam \& Siengthai (2010) CS is known as all economic payments to employee which linked with organizational outcomes. However, compensation system varies pointedly 
across employing organizations and to some degree, across jobs. The compensation system brings out job satisfaction, from the side of employees, the will fill motivate, low absenteeism, low turnover, do to reward in exchange of their services (Quartey \& Attiogbe, 2013).

In the academic literature, several definitions have been provided regarding employee engagement (EE) and literature has shown that $\mathrm{EE}$ is linked with several important organizational outcomes, such as performance for both individual and firm (Scullion, \& Collings, 2010). Similarly, EE is a strong predictor of positive performance of employees in the firm (Kompaso \& Sridevi, 2010). Furthermore, the literature on CS of HRM practices and employee performance has unheeded and specifically evidence linking the influence of EE on CS and EP relationship (Rich, Lepine, \& Crawford, 2010).

Moreover, literature indicated that less attention has been given to CS and EP more specifically in Bangladeshi telecommunication sector. Despite this, studies attempted to consider the influence of CS on EP have reported mixed findings (Hameed, Ramzan, \& Zubair, 2014; Munjuri, 2011; Rizal, Idrus, \& Djumahir, 2014b; Tabiu \& Nura, 2013; Tiwari, 2011). Therefore, a mediating variable is suggested as well as recommended by Baron, \& Kenny (1986). This paper proposes EE as a potential mediator in the connection between CS and EP to stimulate the relationship. Consequently, the aim of this paper to examine the direct connection between compensation system and employee performance as well as mediating role of EE on the relationship between CS and EP.

\section{Literature Review}

Previous studies were conducted with different factors of HRM practices on EP. For example, Suan \& Nasurdin (2014) conducted a study in Asian context specifically in Malaysia 34 upscale hotels investigating the relationship among information sharing, service reward, training, performance appraisal and EP, result revealed that all the factors significantly related to service-oriented contextual performance. Muchhal (2014) investigated the relationship between (3) three factors (i.e. promotion, compensation, performance appraisal) and job performance in Asian context specifically in Indian power and steel company located in Chhattisgarh using 517 samples in quantitative techniques. Result shown that all the factors are correlated to job performance.

Ahmad \& Shahzad (2011) conducted study on the impact of compensation, and promotion on EP in Asian context in Pakistan with 113 samples considering Azad Jammu and Kashmir universities as the study population, findings show that only compensation found significantly related to EP, while promotion was not significantly related to EP. In addition, Bowra, Sharif, Saeed, \& Niazi (2012) conducted a study on the effect of compensation, performance evaluation, and promotion practice on EP in Pakistan banking industry using 235 samples and quantitative analysis, findings revealed promotion practice and performance evaluation were found positive and significantly linked with EP. While compensation found not significant.

Another study by Khalid, Rehman, \& Ilyas (2014) in Pakistan public sector organization investigating the influence of performance evaluation, compensation, career development, 
training, and employee relation on EP using 120 samples in quantitative techniques, result revealed that performance evaluation, compensation, and training are all positive and significantly associated with EP, while employee participation and career development are found not significantly related to EP.

In general, the reviewed studies (Khalid et al., 2014; Muchhal, 2014; Alfes,Truss, Soane, Rees, \& Gateby, 2013; Bowra et al., 2012; Ahmad \& Shahzad, 2011) help us to understand the relationship between CS and EP in different context and countries. However, some studies reported mixed findings between CS and EP (Suan \& Nasurdin, 2014; Bowra et al., 2012; Ahmad \& Shahzad, 2011). In this regard, Baron and Kenny (1986) recommended for using mediating variables where there are inconsistence findings in the literature. Consequently, this study used EE as a mediator on the relationship between CS and EP as well as this study selects to study CS as one of the internal factors of a firm that has great influence on employee behavior as well as employee performance.

\subsection{Relationship between Compensation System and Employee Performance}

For the purpose of this study, the compensation system will be used as an independent variable as compensation system is one of the essential HRM Practices. CS can be described as pay given to employee's by organization resulting from their performance (Wood \& De-Menezes, 1998). It can also be conceptualized as an adequate and equitable remuneration for personnel due to their contributions in achieving organizational goals and objectives (Armstrong \& Brown, 2001). In other words, compensation can be seen as an integral portion of HRM which helps in motivating employees and improving organizational efficiency and effectiveness (Quartey \& Attiogbe, 2013). Similarly, compensation package involves, bonuses, merit pay, leaves, retirement, housing allowances, base pay, commissions, profit sharing and insurance, it can be divided into financial and non-financial rewards (Ghebregiorgis \& Karsten, 2006; Quartey \& Attiogbe, 2013).

Previous studies revealed that compensation system has a relationship with EP. A study conducted by Oluigbo \& Anyiam (2014) in African context specifically in Information Technology (IT) organization Nigeria using 92 samples in chi-square statistics techniques, the result shows that compensation system is positively related to EP. Again, Khalid et al. (2014) carried out a study on the relationship between compensation system and EP in Asian context Pakistan, findings explained compensation has a direct and positive relationship with EP. Similarly, a study conducted by Fisher, Maines, Peffer, \& Sprinkle (2005) investigated the relationship between compensation system and EP, findings revealed compensation system significantly related to EP.

However, some studies contradict the findings of the above-reviewed studies. For instance, Quartey \& Attiogbe (2013) conducted a study in African context specifically in Ghana police sector using 200 samples, the result shows that compensation found moderately significant to EP. Furthermore, a study by Rizal, Idrus, \& Djumahir (2014a) in Asian context Indonesia in particular, with 126 sample of employees using Partial Least Square Modelling (PLS-SEM). It was found that compensation system is significantly related to motivation and organization commitment but not significantly related to EP. Moreover, Tabiu \& Nura (2013) 
investigated the influence of compensation system on EP in Nigerian context with 285 samples, result shown the insignificant relationship between compensation and EP. Moreover, Cheah et al. (2014) carried out a study on compensation and EP, the result shown the insignificant relationship between compensation system and EP. Despite all the evidence from studies in Asian, Western and African countries, there is still lack on the relationship between CS and EP in South-Asian countries particularly in Bangladeshi telecommunication sector. Therefore, the following hypothesis is developed:

H1: There will be a significant posative relationship between compensation system and employee performance of telecommunication service provires in Bangladesh.

\subsection{Relationship between Compensation System and Employee Engagement}

Compensation system denotes to a system that indicates all sorts of financial returns and tangible benefits or services employees gain or receive as a result of an employment relationship (Milkovich \& Newman, 2005). Indriyani \& Heruwasto, (2017); Anitha (2014); and Milkovich \& Newman, (2005) mentioned compensation as one of the factor facilitating the existence of employee engagement and Indriyani \& Heruwasto, (2017) as well as Abel (2013) mentioned in their study that employee engagement increases profit and more success if employee is satisfied. So employee engagement came from the feeling that they got proper compensation about what they already did (Indriyani \& Heruwasto, 2017; Abel, 2013). Hence, the researchers want to say compensation matters and it impacts employee performance. Based on this, we propose another hypothesis that is:

$\mathrm{H} 2$ : There will be a significant positive relationship between compensation system and employee engagement of telecommunication service provires in Bangladesh.

\subsection{Employee Engagement as a Mediator of the Relationship between CS and EP}

EE predicts, employee outcomes, performance and organizational success (Richman, 2006; Baumruk, 2004; Bates, 2004; Harter, Schmidt, \& Hayes, 2002). EE is explained by Shuck \& Wollard (2010) as an individual employee's cognitive, behavioral and emotional state directed toward anticipated firm results. According to May, Gilson, \& Harter (2004), also pointed that EE might be considered as an ancestor to job involvement in that employee who encounter profound engagement in their parts ought to come to relate to their works. Moreover, EE is distinct from quite a few number of related constructs, most particularly organizational citizenship behavior, organizational commitment, and job involvement. Furthermore, EE is now becoming a performance indicator for several organizations in both the private and public sectors (Rees, Alfes, \& Gatenby, 2013) as well as there is scarcity of research on EE in the academic literature (Robinson, Perryman, \& Hayday, 2004).

Previous Studies has shown that EE is correlated towards the commitment of employees and how hard they work as well as EE is associated with results like achievement, better performance of a firm or company (Ghafoor, Qureshi, Khan, \& Hijazi, 2011; Harter, Schmidt, Asplund, Killham, \& Agrawal, 2010). Empirical studies conducted established the relationship between EE and individual performance. Hence, study conducted by Andrew \& Sofian (2012) in Asian context specifically in Malaysian Revenue Board, investigating the 
relationship between individual factors and work outcomes of EE using 104 human resource officers, and found that co-employee support is a main factor that effects both measures of engagement and the employee performance.

Christian et al. (2011) investigated the relationship between EE and task and contextual performance, result revealed that $\mathrm{EE}$ influence employee behavior in an organization and the study suggest more investigation need to be done on the EE as a construct. Additionally, Crawford, LePine, \& Rich (2010), examine the connection between EE, resources and job demands, a result explained positive relationship between the study variables. Similarly, Salanova, Agut, \& Peiro (2005) investigated the relationship between EE and EP, the study reported the positive significant relationship between EE and EP. The available literature reviewed established that EE has a significant impact on employee performance. Despite all the evidence from studies in Asian, Western and African countries, there is still lack on the relationship between EE and EP in South-Asian countries particularly in Bangladeshi telecommunication sector. Therefore, the following hypothesis is developed:

H3: There will be significant positive relationship between employee engagement and employee performance of telecommunication service provires in Bangladesh.

Moreover, several studies conveyed mixed results about CS effects on EP (Suan \& Nasurdin, 2014; Bowra et al., 2012; Ahmad \& Shahzad, 2011) as well as the mediating role of EE has been neglected in the academic literature (Shantz, Alfes, Truss, \& Soane, 2013). In this regard, Baron \& Kenny (1986) recommended for using mediating variables where there are inconsistence findings in the literature. In this regard, the present study used EE to mediate the relationship between CS and EP, specifically in Bangladeshi telecommunication sector. Therefore, the following hypothesis is developed:

H4: Employee engagement mediates the relationship between compensation system and employee performance of telecommunication service provires in Bangladesh.

\subsection{Conceptual Framework and Underpinning Theory of this Study}

The research framework is framed to explore the direct connection between compensation system and employee performance as well as mediating role of EE on the relationship between CS and EP. Particularly in this study, EP of telecommunication service provider in Bangladesh to be tested. In this regard, Social Exchange (SE) theory is considered as underpinning theory of this study. SE theory explains how interactions develop over time and personnel are expected to share their engagement for resources and benefits provided by their organization. This is in line with explanation of engagement as a both way connection among the employee and employer (Robinson et al., 2004). Hence, based on the above argument the present study has used social exchange theory to explain the research framework which is shown in Figure 1. 


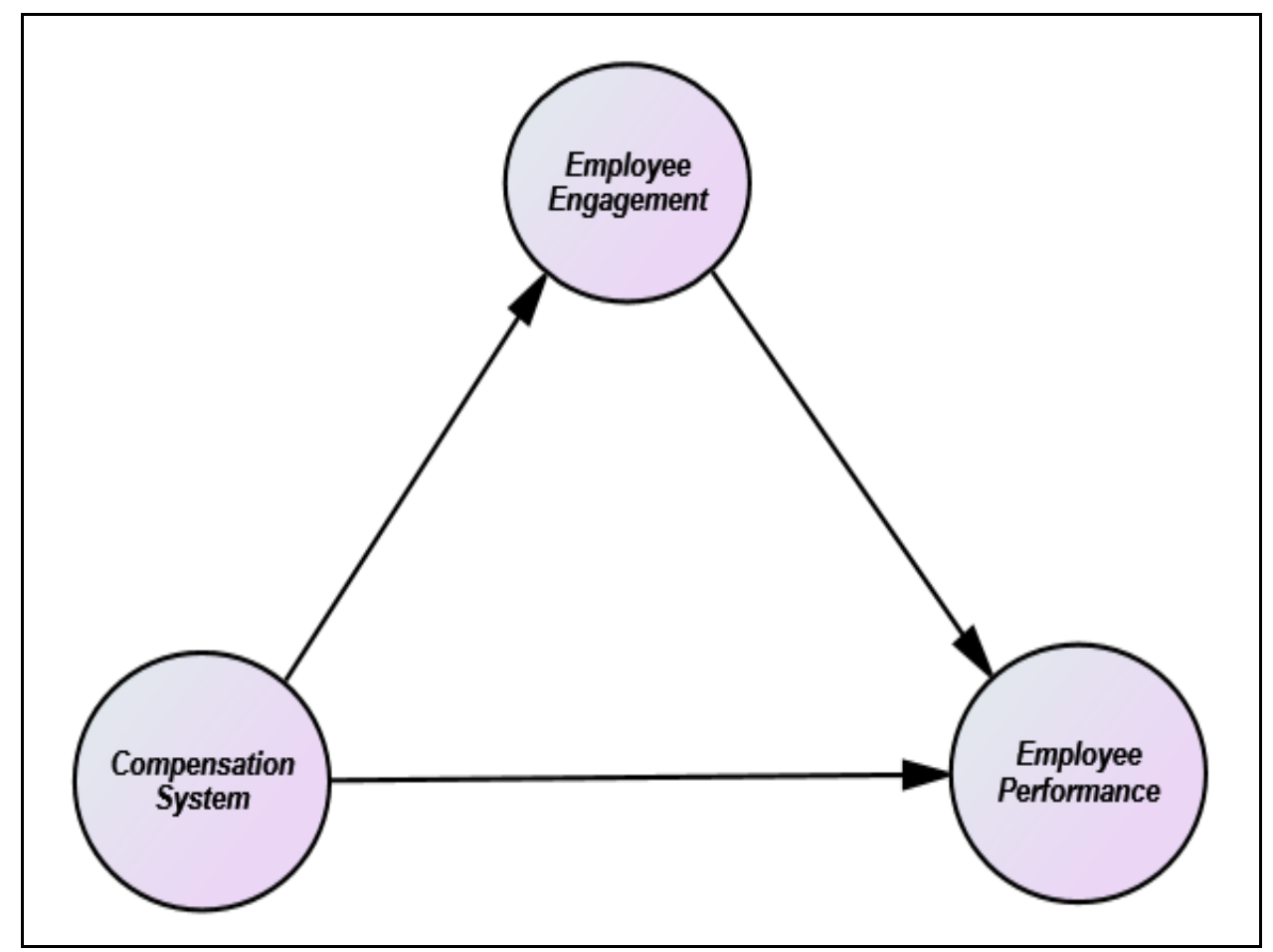

Figure 1. Research Framework

\section{Research Methodology}

The determination of this study is to investigate the relationship of CS and EP with EE as a mediator. Therein, survey was conducted as well as perceptions of employees working in three major telecommunication service providers (i.e. Robi Axiata Limited, Grameenphone Limited, and Banglalink Digital Communications Limited) in senior positions in the service branches were obtained to analyze the relationships. The branches of the companies were in Dhaka, Chittagong, Rajshahi, and Sylhate from the Bangladeshi Peninsula were targeted. A self-administered questionnaire was distributed to the randomly selected employees. A total of 200 usable questionnaires were received back. Grounded on gender, male constituted 58\% while female represented $42 \%$ of the sample population.

The survey consisted of measures to obtain data pertaining to employee performance, compensation system, and employee engagement. The measures for compensation system was assessed through an instrument developed by Isabel \& Ma-Pilar, (2014) having four (4) items. Employee engagement was assessed through an instrument developed by Hoque, Gwadabe, \& Rahman, (2017d) and Schaufeli, Salanova, Gonzalez-Roma, \& Bakker (2002) having six (6) items in their studies. This scale has been deployed in a variety of different occupational and geographical settings including Asia, Europe, Africa and North America (Seppala, Mauno, Feldt, Hakanen, Kinnunen, Tolvanen, \& Schaufeli, 2009; Xanthopoulou, Bakker, Demerouti, \& Schaufeli, 2009). EP has been categorized into two dimensions by Borman \& Motowidlo (1993), task performance and contextual performance. Similarly, Allworth \& Hesketh (1999) classified EP into three dimensions includes; contextual performance, task performance, and adaptive performance. For the purpose of this study the 
measures for employee performance was assessed through an instrument developed by Borman \& Motowidlo (1993) having ten items divided into two dimensions of employee performance (i.e. task performance and contextual performance) and respondents were made to respond and rate using 7-point interval scale with 1 denoting strongly disagree and 7 as strongly agree with the items statement.

Hoque, Awang, Muda, \& Salleh (2018); Awang, Ahmed, Hoque, Siddiqui, Dahri, \& Muda, (2017a); Awang, Hoque, Muda, \& Salleh, (2017b); Hoque et al. (2017a); Hoque, Awang, \& Siddiqui, (2017b); Awang, Jusoff, Salleh, \& Muda, (2017c); Hoque, Gwadabe, \& Rahman, (2017d); Hoque, \& Awang, (2016b); Kashif, Samsi, Awang, \& Mohamad (2016); Awang, Afthanorhan, Mohamad, \& Asri (2015a); and Awang (2014) mentioned that second generation method of multivariate analysis technique is SEM, and which is developed to cater limitations in the traditional Ordinary Least Squares (OLS) and the analysis for latent constructs is no longer appropriate with traditional OLS. Thus the researchers employed SEM so as to keep pace with the advancement in research methodology. Not only that, using IBM-SPSS-AMOS software, the researchers converted their theoretical framework directly into the Amos Graphics for analysis. The researcher validated the measurement model of the latent constructs in SEM using Confirmatory Factor Analysis (CFA) procedure. Once validated, the researcher assembled the constructs into the structural model and execute the Structural Equation Modeling (SEM) procedure. Consequently, analyzing and testing the theory using IBM-SPSS-AMOS software is fast, efficient and robust (Hoque et. al., 2017a; Awang, 2015). Hence, this study employed IBM-SEM-AMOS software for analysis and testing the hypotheses

\section{Results}

\subsection{Measurement Model}

Before modelling the structural model and executing SEM, the study needs to validate the measurement model of latent constructs for unidimensionality, validity, and reliability (Hoque et al., 2018; Hoque \& Awang, 2016a; Hoque \& Awang, 2016b; Hoque et. al., 2017a; Hoque et. al., 2017b; Awang, 2015; Awang et al.2015a). Unidimensionality is achieved as the factor loading for all items are positive with a minimum value of 0.6 . The Construct validity is achieved as the fitness indexes for the measurement model meet three model fit categories. The Discriminant validity is achieved as all the constructs are not highly correlated. The Convergent validity is also achieved as the value of Average Variance Extracted (AVE) meet the minimum value of 0.5 (Hair et al., 2014). The Construct reliability is achieved as the values of Composite Reliability (CR) and Average Variance Extracted (AVE) reached the minimum value of 0.6 and 0.5 respectively recommended by Hoque et al. (2018), Hoque et. al. (2017a), Hoque et al. (2017b), Hoque et al. (2017c), Hoque et al. (2017d), Awang (2015), Awang et al. (2015a), and Hair et al. (2014). The Internal reliability among the items is achieved as the value of Cronbach Alpha reach the minimum value of 0.7 (Fornell \& Larcker, 1981; Nunnally, 1978). The fitness indexes shown in Figure 2 indicate the measurement model of the three latent constructs (CS, EE, and EP) have met the requirement for Construct validity. 


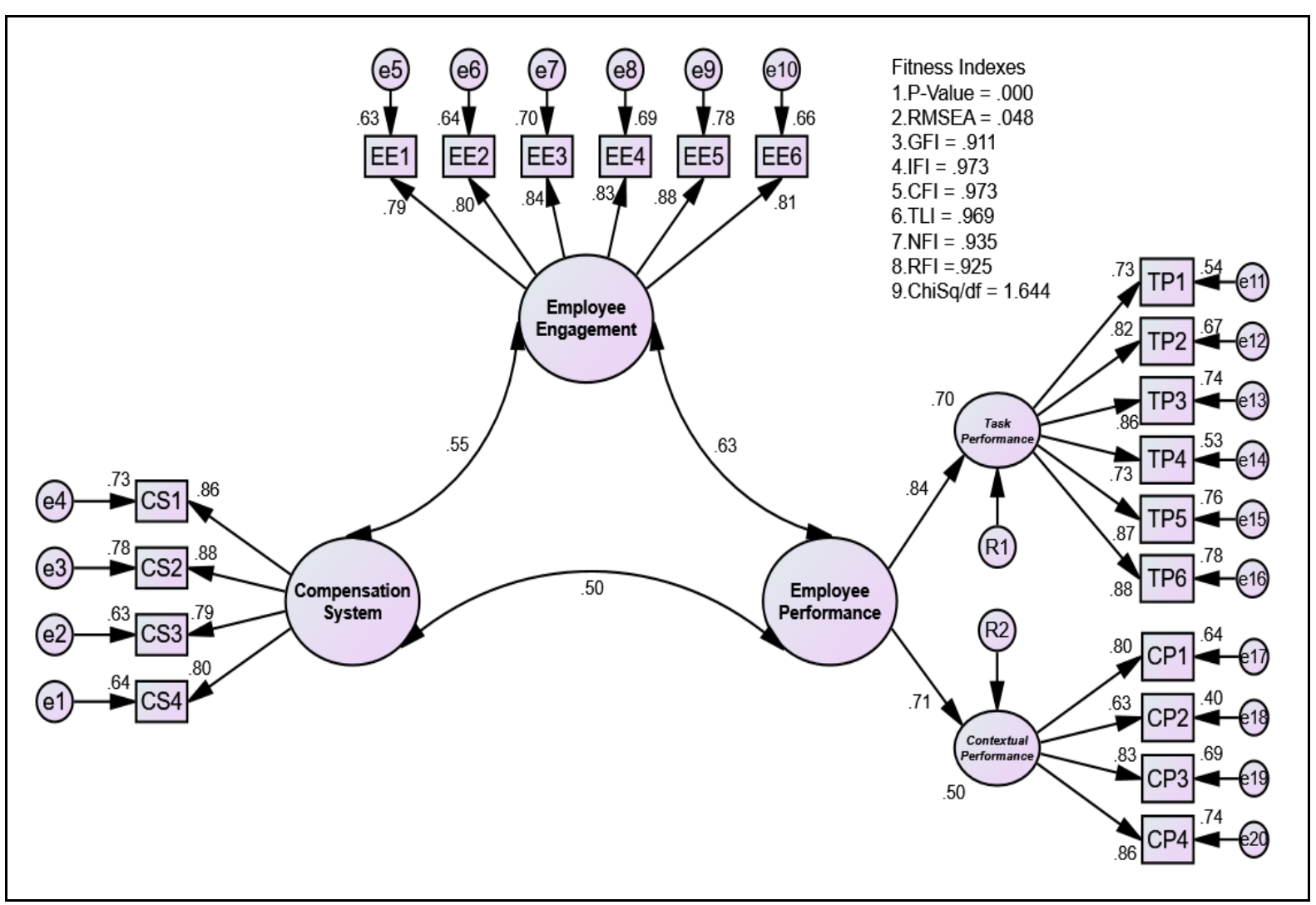

Figure 2. The Pooled CFA Results and the Output Showed All Fitness Indexes Achieved

The values of factor loading for every item together with the Cronbach Alpha, CR and AVE for every construct as shown in Table 1 indicates all latent constructs (CS, EE, and EP) have achieved Convergent Validity, Construct Reliability and Internal Reliability.

Table 1. The Composite Reliability and Average Variance Extracted

\begin{tabular}{|c|c|c|c|c|c|}
\hline Construct & Item & $\begin{array}{c}\text { Factor } \\
\text { Loading }\end{array}$ & $\begin{array}{c}\text { Cronbach's } \\
\text { Alpha }\end{array}$ & $\begin{array}{c}\text { Composite } \\
\text { Reliability }(\mathbf{C R}) \\
\text { (above } 0.6)\end{array}$ & $\begin{array}{c}\text { Average Variance } \\
\text { Extracted (AVE) } \\
\text { (above } 0.5 \text { ) }\end{array}$ \\
\hline & CS1 & .86 & \multirow{4}{*}{0.900} & \multirow{4}{*}{0.901} & \multirow{4}{*}{0.695} \\
\hline Compensation & CS 2 & .88 & & & \\
\hline \multirow[t]{4}{*}{ System (CS) } & CS 3 & .79 & & & \\
\hline & CS 4 & .80 & & & \\
\hline & EE 1 & .79 & \multirow{6}{*}{0.928} & \multirow{6}{*}{0.928} & \multirow{6}{*}{0.682} \\
\hline & EE 2 & .80 & & & \\
\hline Employee & EE 3 & .84 & & & \\
\hline \multirow[t]{3}{*}{ Engagement (EE) } & EE 4 & .83 & & & \\
\hline & EE 5 & .88 & & & \\
\hline & EE 6 & .81 & & & \\
\hline Employee & $\mathrm{TP}$ & .84 & \multirow{2}{*}{0.914} & \multirow{2}{*}{0.752} & \multirow{2}{*}{0.605} \\
\hline Performance (EP) & $\mathrm{CP}$ & .71 & & & \\
\hline
\end{tabular}




\begin{tabular}{llrlll}
\hline & EP 1 & .73 & & & \\
& EP 2 & .82 & & & \\
Task & EP 3 & .86 & 0.968 & 0.923 & \\
Performance (TP) & EP 4 & .73 & 0.921 & & \\
& EP 5 & .87 & & & \\
& EP 6 & .88 & & & \\
& CP 1 & .80 & & 0.616 \\
Contextual & CP 2 & .63 & 0.856 & & \\
Performance (CP) & CP 3 & .83 & & & \\
& CP 4 & .86 & & & \\
\hline
\end{tabular}

The Discriminant validity is assessed through correlation and also through Discriminant validity index summary. According to Hoque et al. (2018), Hoque et al. (2017a), Hoque et al. (2017c), Awang (2015), and Awang et al. (2015a), one of the criteria for Discriminant validity is the correlation between exogenous constructs must not exceed 0.85. Table 2 which indicated the Discriminant Validity Index Summary as well as the diagonal value in Table 2 is square-root of AVE for the respective constructs, while other values are the correlation between constructs. The Discriminant validity of the constructs is achieved when the diagonal values (i.e. the square-root of AVE for the respective constructs) are greater than any values in their rows, and columns respectively (Hoque et al., 2018; Hoque et al., 2017a; Hoque et al., 2017b; Hoque et al., 2017d; Awang, 2015a; Hair et al., 2014).

Table 2. Discriminant Validity Index Summary

\begin{tabular}{lccc}
\hline Construct & $\begin{array}{c}\text { Compensation } \\
\text { System (CS) }\end{array}$ & $\begin{array}{c}\text { Employee } \\
\text { Engagement (EE) }\end{array}$ & $\begin{array}{c}\text { Employee } \\
\text { Performance (EP) }\end{array}$ \\
\hline Compensation System (CS) & $\mathbf{0 . 8 3 3}$ & & \\
\hline Employee Engagement (EE) & 0.546 & $\mathbf{0 . 8 2 5}$ & \\
\hline Employee Performance (EP) & 0.502 & 0.633 & $\mathbf{0 . 7 7 7 0}$ \\
\hline
\end{tabular}

The correlation value of latent constructs CS and EE is 0.546, the correlation value of latent constructs CS and EP is 0.502 and correlation value of EE and EP is 0.633. As the value in diagonal is greater than any values in its row and column, this study accomplishes that the discriminant validity is achieved for the model (Hoque et al., 2018; Hoque et al., 2017a; Hoque et al., 2017b; Hoque et al., 2017c; Hoque et al., 2017d; Kashif et al., 2016; Awang et al., 2015a; Fornell \& Larcker, 1981).

\subsection{Structural Model}

As shown in Figure 3, three hypotheses $\left(\mathrm{H}_{1}, \mathrm{H}_{2}\right.$, \& $\left.\mathrm{H}_{3}\right)$ are supported. $\mathrm{In}_{1}$, compensation system has a significant positive direct effect on employee performance of a firm $(\beta=0.151$, $\mathrm{P}=.005)$. In $\mathrm{H}_{2}$, compensation system has a significant positive direct effect on employee engagement $(\beta=0.468, \mathrm{P}=.000)$, in $\mathrm{H}_{3}$, where employee engagement also has a significant 
positive direct effect on employee performance $(\beta=0.403, \mathrm{P}=.000)$. The structural model explains $44 \%$ variance in employee performance.

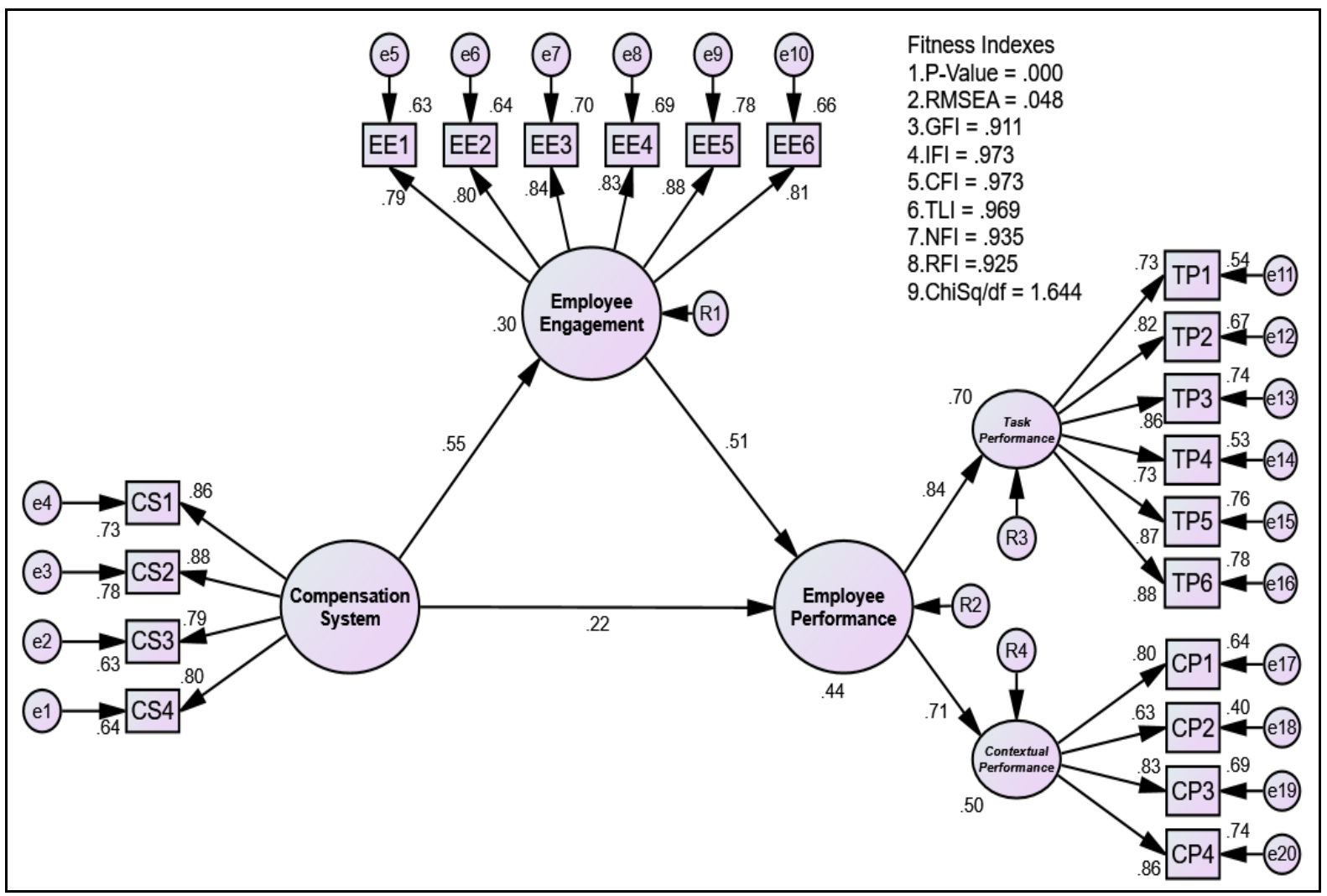

Figure 3. The Standardized Regression Weights for Every Path in the Model

\subsection{Test of Mediation}

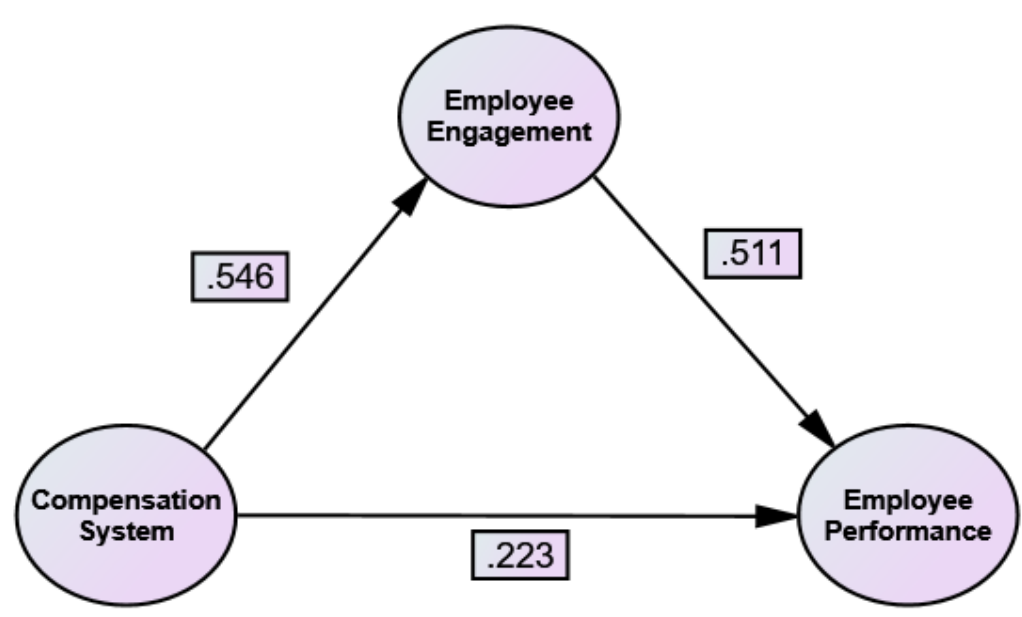

Indirect effect $=0.546 \times 0.511=0.279$ and direct effect $=0.223$. So, indirect effect $>$ direct effect and both indirect paths (i.e., CS to EE and EE to EP) are significant. Moreover, direct path is still significant. Therefore, partial mediation occurs.

Figure 4. The Standardized Regression Weights for the Model 
As a result, employee engagement partially mediates the relationship between compensation system and employee performance since both indirect paths (CS to EE and EE to EP) are significant and the indirect effect is higher than the direct effect as well as the direct effect is still significant after mediator enters the model.

\subsection{Confirming the Mediation Result through Bootstrapping}

It is imperative to reconfirm the result of the mediation test using the re-sampling procedure known as bootstrapping to reconfirm the hypothesis testing result of indirect effect (Hoque $e t$ al., 2017b; Hoque et al., 2017c; Hoque et al., 2017d; Kashif et al., 2016; Awang et al., 2015a; Awang et al., 2015; Hair et al., 2014). The process allows for sampling with replacement between 500-5000 samples from the existing dataset. The study could compare the bootstrapping results with the results using normal modeling procedure. If there is any difference between the two, then the bootstrapping result will be admitted. The bootstrapping result with $\mathrm{n}=5000$ and bias-corrected confidence 0.95 is shown in Table 3 .

Table 3. Summary of Bootstrapping Result

\begin{tabular}{|c|c|c|}
\hline & Indirect Effec & Direct Effect \\
\hline Bootstrapping Results & 0.279 & 0.223 \\
\hline Does mediation occur? & \multicolumn{2}{|c|}{$\begin{array}{l}\text { The mediation occurs since the indirect effect is greater than } \\
\text { direct effect. }\end{array}$} \\
\hline Bootstrapping p-value & 0.001 & 0.012 \\
\hline Results & Significant & Significant \\
\hline Type of Mediation & \multicolumn{2}{|c|}{ Partial Mediation since the direct is still significant. } \\
\hline
\end{tabular}

Table 3 shows the beta estimate of both the indirect effect and direct effects of compensation system on employee performance $(\beta)=0.279$ and 0.223 respectively. Furthermore, it shows the P-value of indirect and direct effects for the compensation system on employee performance ( $\mathrm{P}$-value $=0.001$ and 0.012 respectively). Based on the bootstrapping results in Table 3, it is evident that employee engagement partially mediates the relationship between compensation system on employee performance. Consequently, the $\mathrm{H}_{4}$ of this study which posited that employee engagement mediates the relationship between compensation system on employee performance is also supported by the data of this study.

\section{Conclusion}

The paper highlights key ingredients that could notably enhance employee performance and how employee engagement could contribute towards it. Employee engagement harvests vital competitive factors in a firm which ultimately lead towards satisfaction as well as competitive advantage and achievement of employee performance target. In this paper, we have tried to underscore how employee engagement can interact in the relationship between corporate entrepreneurship and employee performance. The paper argues and found that compensation system has a significant positive effect on employee performance. Accordingly, the paper also emphasizes that the compensation system can especially enhance employees 
work wellbeing hence resulting in employee engagement. However, with some robust empirical evidence by the data of this study, the manuscript also recommends that employee engagement mediates the relationship between compensation system and employee performance. Hence, future researchers might focus on job design as an another independent variable as well as job satisfaction as a mediating variable to see whether good HR management practice helps to get better employee performance or not.

\section{References}

Abbas, Q., \& Yaqoob, S. (2009). Effect of leadership development on employee performance in Pakistan. Pakistan Economic and Social Review, 269-292.

Abel, M. (2013). The social and financial benefits of developing employee satisfaction. International Journal of Management \& Information Systems, 17(2), 83-88. https://doi.org/10.19030/ijmis.v17i2.7711

Abu, J. I., Yusof, N. A., \& Wira, M. S. M. (2010). The organizational performance of housing developers in Peninsular Malaysia. International Journal of Housing Markets and Analysis, 3(2), 146-162. https://doi.org/10.1108/17538271011049768

Ahmad, S., \& Shahzad, K. (2011). HRM and employee performance: A case of university teachers of Azad Jammu and Kashmir (AJK) in Pakistan.. African Journal of Business Management, 5(13), 5249-5253.

Alfes, K., Truss, C., Soane, E. C., Rees, C., \& Gatenby, M. (2013). The relationship between line manager behavior, perceived HRM practices, and individual performance: examining the mediating role of engagement. Human Resource Management, 52(6), 839-859. https://doi.org/10.1002/hrm.21512

Allworth, E., \& Hesketh, B. (1999). Construct-oriented Biodata: Capturing Change-related and Contextually Relevant Future Performance. International Journal of Selection and Assessment, 7(2), 97-111. https://doi.org/10.1111/1468-2389.00110

Andersén, J. (2010). A critical examination of the EO-performance relationship. International Journal of Entrepreneurial Behavior \& Research, 16(4), 309-328. https://doi.org/10.1108/13552551011054507

Andrew, O. C., \& Sofian, S. (2012). Individual factors and work outcomes of employee engagement. Procedia-Social and Behavioral Sciences, 40, 498-508. https://doi.org/10.1016/j.sbspro.2012.03.222

Anitha, J. (2014). Determinants of employee engagement and their impact on employee performance. International Journal of Productivity and Performance Management, 63(3), 308-323. https://doi.org/10.1108/IJPPM-01-2013-0008

Armstrong, M., \& Brown, D. (2001). New dimensions in pay management: CIPD Publishing.

Arshadi, N. (2010). Basic need satisfaction, work motivation, and job performance in an industrial company in Iran. Procedia-Social and Behavioral Sciences, 5, 1267-1272. 
https://doi.org/10.1016/j.sbspro.2010.07.273

Awang, Z. (2014). A Handbook on SEM for Academicians and Practitioners: the step by step practical guides for the beginners. Bandar Baru Bangi: MPWS Rich Resources.

Awang, Z. (2015). SEM made simple: A Gentle Approach to Learning Structural Equation Modeling. Bandar Baru Bangi: MPWS Rich Resources.

Awang, Z., Afthanorhan, A., Mohamad, M., \& Asri, M. A. M. (2015a). An evaluation of measurement model for medical tourism research: the confirmatory factor analysis approach. International Journal of Tourism Policy, 6(1), 29-45. https://doi.org/10.1504/IJTP.2015.075141

Awang, Z., Ahmed, U., Hoque, A. S. M. M., Siddiqui, B. A., Dahri, A. S., \& Muda, H. (2017a). The Mediating Role of Meaningful Work in the Relationship Between Career Growth Opportunities and Work Engagement. International Academic Confernce on Business and Economics (IACBE 2017), Faculty of Economics and Management Sciences (FESP), Universiti Sultan Zainal Abidin (UniSZA), October 07-08.

Awang, Z., Hoque, A. S. M. M., Muda, H., \& Salleh, F. (2017b). The Effects of Crowdfunding on Entrepreneur's Self-Belief. International Academic Confernce on Business and Economics (IACBE 2017), Faculty of Economics and Management Sciences (FESP), Universiti Sultan Zainal Abidin (UniSZA), October 07-08.

Azhdar, K., Samira, S. A., \& Sarani, B. (2015). The Influence of HR Practices on Business Strategy and Firm Performance: The Case of Banking Industry in Iran The IUP Journal of Management Research, Vol. XIV,(No. 1,).

Baron, R. M., \& Kenny, D. A. (1986). The moderator-mediator variable distinction in social psychological research: Conceptual, strategic, and statistical considerations. Journal of personality and social psychology, 51(6), 1173. https://doi.org/10.1037/0022-3514.51.6.1173

Bates, S. (2004). Getting engaged. HR magazine, 49(2), 44-51.

Baumruk, R. (2004). The missing link: the role of employee engagement in business success. Workspan, 47(11), 48-52.

Borman, W. C., \& Motowidlo, S. (1993). Expanding the criterion domain to include elements of contextual performance. Personnel Selection in Organizations; San Francisco: Jossey-Bass, 71.

Bowra, Z. A., Sharif, B., Saeed, A., \& Niazi, M. K. (2012). Impact of human resource practices on employee perceived performance in banking sector of Pakistan. African Journal of Business Management, 6(1), 323-332.

Cardy, R. L., \& Selvarajan, T. (2004). Assessing ethical behavior: Development of a behaviorally anchored rating scale. Paper presented at the 47th Midwest Academy of Management Meeting.

Cekmecelioglu, H. G., \& Günsel, A. (2011). Promoting creativity among employees of 
mature industries: the effects of autonomy and role stress on creative behaviors and job performance. Procedia-Social and Behavioral Sciences, 24, 889-895. https://doi.org/10.1016/j.sbspro.2011.09.020

Cheah, C. M., Chuah, F. H., Lim, J. H., Lim, W. C., \& Lim, Y. H. (2014). Human resource management practices as a determinant of Organizational citizenship behaviours: A study among banking staffs. UTAR.

Chen, C. H., Lee, T., Hou, T., Chen, C., Chen, C., Hsu, J., \& Jin, Y. (2004). Stress memorization technique (SMT) by selectively strained-nitride capping for sub-65nm high-performance strained-Si device application. Paper presented at the VLSI Technology, 2004. Digest of Technical Papers. 2004 Symposium on. https://doi.org/10.1109/VLSIT.2004.1345390

Christian, M. S., Garza, A. S., \& Slaughter, J. E. (2011). Work engagement: A quantitative review and test of its relations with task and contextual performance. Personnel Psychology, 64(1), 89-136. https://doi.org/10.1111/j.1744-6570.2010.01203.x

Crawford, E. R., LePine, J. A., \& Rich, B. L. (2010). Linking job demands and resources to employee engagement and burnout: a theoretical extension and meta-analytic test. Journal of applied psychology, 95(5), 834. https://doi.org/10.1037/a0019364

Fisher, J. G., Maines, L. A., Peffer, S. A., \& Sprinkle, G. B. (2005). An experimental investigation of employer discretion in employee performance evaluation and compensation. The Accounting Review, 80(2), 563-583. https://doi.org/10.2308/accr.2005.80.2.563

Fornell, C., \& Larcker, D. F. (1981), Structural equation models with unobservable variables and measurement error: Algebra and statistics. Journal of Marketing Research, 18(3), 328-388. https://doi.org/10.2307/3150980

Ghafoor, A., Qureshi, T. M., Khan, M. A., \& Hijazi, S. T. (2011). Transformational leadership, employee engagement and performance: Mediating effect of psychological ownership. African Journal of Business Management, 5(17), 7391-7403. https://doi.org/10.5897/AJBM11.126

Ghebregiorgis, F., \& Karsten, L. (2006). Human resource management practices in Eritrea: challenges and prospects. Employee Relations, 28(2), 144-163. https://doi.org/10.1108/01425450610639374

Hair, J. F., Hult, G. T., Ringle, C. M., Sarstedt, M. (2014). A Primer on Partial Least Squares Structural Equation Modelling. Thousand Oaks, California: SAGE Publications, Inc.

Hameed, A., Ramzan, M., \& Zubair, H. M. K. (2014). Impact of Compensation on Employee Performance (Empirical Evidence from Banking Sector of Pakistan). International Journal of Business and Social Science, 5(2), 28-32.

Harter, J. K., Schmidt, F. L., \& Hayes, T. L. (2002). Business-unit-level relationship between employee satisfaction, employee engagement, and business outcomes: a meta-analysis. Journal of applied psychology, 87(2), 268. https://doi.org/10.1037/0021-9010.87.2.268 
Harter, J. K., Schmidt, F. L., Asplund, J. W., Killham, E. A., \& Agrawal, S. (2010). Causal impact of employee work perceptions on the bottom line of organizations. Perspectives on Psychological Science, 5(4), 378-389. https://doi.org/10.1177/1745691610374589

Hoque, A. S. M. M., \& Awang, Z. (2016a). The Sway of Entrepreneurial Marketing on Firm Performance: Case of Small and Medium Enterprises (SMEs) in Bangladesh, Terengganu International Business and Economics Conference (TiBEC-V), Terengganu, Universiti Teknologi Mara (UiTM), pp. 174-194.

Hoque, A. S. M. M., \& Awang, Z. (2016b). Exploratory Factor Analysis of Entrepreneurial Marketing: Scale Development and Validation in the SME context of Bangladesh, International Social Sciences and Tourism Research Conference, Terengganu, UniSZA, pp. 20-22.

Hoque, A. S. M. M., Awang, Z., \& Salam, S. (2017a). The Effects of Relationship Marketing on Firm Performance: Small and Medium Enterprises (SMEs) in Bangladesh, 1st International Conference on Business and Management (ICBM-2017), BRAC Business School (BBS), BRAC University, Dhaka, Bangladesh, September 21-22.

Hoque, A. S. M. M., Awang, Z., \& Siddiqui, B. A. (2017b). Technopreneurial Intention among University Students of Business Courses in Malaysia: A Structural Equation Modeling. International Journal of Entrepreneurship and Small \& Medium Enterprise (IJESME), 4, $1-16$.

Hoque, A. S. M. M., Awang, Z., Jusoff, K., Salleh, F., \& Muda, H. (2017c). Social Business Efficiency: Instrument Development and Validation Procedure using Structural Equation Modelling, International Business Management, 11(1), 222-231.

Hoque, A. S. M. M., Awang, Z., Muda, H., \& Salleh, F. (2018). Ramification of crowdfunding on Bangladeshi entrepreneur's self-efficacy. Accounting, 4(4), 129-138. https://doi.org/10.5267/j.ac.2018.4.001

Hoque, A. S. M. M., Gwadabe, U. M., \& Rahman, M. A. (2017d). Corporate Entrepreneurship Upshot on Innovation Performance: The Mediation of Employee Engagement. Journal of Humanities, Language, Culture and Business, 1(6), 54-67.

Indriyani, A. U., \& Heruwasto, I. I. (2017). Effect of Compensation and Benefit to Employee Engagement through Organisation Brand in Indonesia's Startup Company. Journal Manajemen Teori dan Terapan, 10(1), 83-92.

Isabel, M. P., \& Ma, P. P. (2014). Managing innovative work behavior: the role of human resource practices. Personnel Review, 184-208. https://doi.org/10.1108/PR-11-2012-0199

Islam, M. Z., \& Siengthai, S. (2010). Human Resource Management Practices and Firm Performance Improvement in Dhaka Export Processing Zone. Research and Practice in Human Resource Management, 18(1), 60-77.

Kashif, M., Samsi, S. Z. M., Awang, Z., \& Mohamad, M. (2016). EXQ: measurement of 
healthcare experience quality in Malaysian settings: A contextualist perspective. International Journal of Pharmaceutical and Healthcare Marketing, 10(1), 27-47. https://doi.org/10.1108/IJPHM-03-2015-0011

Khalid, M. M., Rehman, C. A., \& Ilyas, M. (2014). HRM Practices and Employee Performance in Public Sector Organizations in Pakistan: An Empirical study. International Journal of Management Sciences and Business Research, 3(2), 69-81.

Kompaso, S. M., \& Sridevi, M. S. (2010). Employee engagement: The key to improving performance. International Journal of Business and Management, 5(12), 89-97. https://doi.org/10.5539/ijbm.v5n12p89

Laitinen, E. K. (2009). Importance of performance information in managerial work. Industrial Management \& Data Systems, $109(4), \quad 550-569$. https://doi.org/10.1108/02635570910948669

May, D. R., Gilson, R. L., \& Harter, L. M. (2004). The psychological conditions of meaningfulness, safety and availability and the engagement of the human spirit at work. Journal of occupational and organizational psychology, 77(1), 11-37. https://doi.org/10.1348/096317904322915892

Milkovich, G. T., \& Newman, J. M. (2005). Compensation. 8th ed. Boston, MA: McGraw-Hill.

Muchhal, D. S. (2014). HR Practices and Job Performance. IOSR Journal of Humanities And Social Science (IOSR-JHSS), 19(4), 55-61. https://doi.org/10.9790/0837-19415561

Muchinsky, P. M. (2003). Psychology: Applied to work. Belmont, CA: Wadsworth/Thomson Learning: Inc.

Munjuri, M. G. (2011). The effect of human resource management practices in enhancing employee performance in catholic institutions of Higher Learning in Kenya. International Journal of Business Administration, 2(4), 189-206. https://doi.org/10.5430/ijba.v2n4p189

Nunnally, J. C. (1978). Psychometric Theory (2 ${ }^{\text {nd }}$ ed.). New York: McGraw-Hill.

Obi-Anike, H. O., \& Ekwe, M. C. (2014). Impact of Training and Development on Organizational Effectiveness: Evidence from Selected Public Sector Organizations in Nigeria. European Journal of Business and Management, 6(29), 66-75.

Oluigbo, I., \& Anyiam, K. (2014). The Role of Compensation On Employee Performance in an Information Technology Organization. IJRIT International Journal of Research in Information Technology, 2(4), 548-558.

Quartey, S. H., \& Attiogbe, E. J. (2013). Is there a link between compensation packages and job performance in the Ghana police service? African Journal of Business Management, 7(44), 4398-4406.

Rees, C., Alfes, K., \& Gatenby, M. (2013). Employee voice and engagement: connections and consequences. The international journal of human resource management, 24(14), 2780-2798. 
https://doi.org/10.1080/09585192.2013.763843

Rich, B. L., Lepine, J. A., \& Crawford, E. R. (2010). Job engagement: Antecedents and effects on job performance. Academy of management journal, 53(3), 617-635. https://doi.org/10.5465/amj.2010.51468988

Richman, A. (2006). Everyone wants an engaged workforce how can you create it. Workspan, 49(1), 36-39.

Rizal, M., Idrus, M., \& Djumahir, M. (2014a). Effect of Compensation on Motivation, Organizational Commitment and Employee Performance (Studies in Local Revenue Management in Kendari City). International Journal of Business and Management Invention, 3(2), 64-79.

Rizal, M., Idrus, M., \& Djumahir, M. (2014b). Effect of Compensation on Motivation, Organizational Commitment and Employee Performance Studies in Local Revenue Management in Kendari City. International Journal of Business and Management Invention, 3(2), 64-79.

Robinson, D., Perryman, S., \& Hayday, S. (2004). The drivers of employee engagement, Institute of Employment Studies. Report 405: United Kingdom, London: Publisher unknown.

Salanova, M., Agut, S., \& Peiro, J. M. (2005). Linking organizational resources and work engagement to employee performance and customer loyalty: the mediation of service climate. Journal of applied psychology, 90(6), 12-17. https://doi.org/10.1037/0021-9010.90.6.1217

Schaufeli, W. B., Salanova, M., Gonzalez, R. V., \& Bakker, A. B. (2002). The measurement of engagement and burnout: A two sample confirmatory factor analytic approach. Journal of Happiness studies, 3(1), 71-92. https://doi.org/10.1023/A:1015630930326

Scullion, H., \& Collings, D. (2010). Global talent management: Routledge.

Seppala, P., Mauno, S., Feldt, T., Hakanen, J., Kinnunen, U., Tolvanen, A., \& Schaufeli, W. (2009). The construct validity of the Utrecht Work Engagement Scale: Multisample and longitudinal evidence. Journal of Happiness Studies, 10(4), 459-481. https://doi.org/10.1007/s10902-008-9100-y

Shantz, A., Alfes, K., Truss, C., \& Soane, E. (2013). The role of employee engagement in the relationship between job design and task performance, citizenship and deviant behaviours. The international journal of human resource management, 24(13), 2608-2627. https://doi.org/10.1080/09585192.2012.744334

Shuck, B., \& Wollard, K. (2010). Employee engagement and HRD: A seminal review of the foundations. Human Resource Development Review, 9(1), 89-110. https://doi.org/10.1177/1534484309353560

Suan, C. L., \& Nasurdin, M. A. (2014). Do Human Resource Management Practices Affect Employees' Service-Oriented Organizational Citizenship Behavior? Evidence from the Malaysian Hotel Industry. World Applied Sciences Journal, 31(2), 253-266. 


\section{Macrothink}

International Journal of Human Resource Studies

ISSN 2162-3058 2018, Vol. 8, No. 3

Tabiu, A., \& Nura, A. A. (2013). Assessing the effects of human resource management (HRM) practices on employee job performance: A study of Usmanu Danfodiyo University Sokoto. Journal of Business Studies Quarterly, 5(2), 247-259.

Tiwari, P. (2011). Impact of selected HRM practices on perceived employee performance: An empirical study. Global Management Journal, 3(1/2), 37-43.

Trehan, S., \& Setia, K. (2014). Human Resource Management Practices and Organizational Performance: An Indian Perspective. Global Journal of Finance and Management, 6(8), 789-796.

Tsui, P. L., Lin, Y. S., \& Yu, T. H. (2013). The influence of psychological contract and organizational commitment on hospitality employee performance. Social Behavior and Personality: an international journal, 41(3), 443-452. https://doi.org/10.2224/sbp.2013.41.3.443

Viswesvaran, C., \& Ones, D. S. (2000). Perspectives on models of job performance. International Journal of Selection and assessment, 8(4), 216-226. https://doi.org/10.1111/1468-2389.00151

Wood, S., \& De Menezes, L. (1998). High commitment management in the UK: Evidence from the workplace industrial relations survey, and employers' manpower and skills practices survey. Human Relations, 51(4), 485-515. https://doi.org/10.1177/001872679805100403

Xanthopoulou, D., Bakker, A. B., Demerouti, E., \& Schaufeli, W. B. (2009). Work engagement and financial returns: A diary study on the role of job and personal resources. Journal of Occupational and Organizational Psychology, 82(1), 183-200. https://doi.org/10.1348/096317908X285633

\section{Copyright Disclaimer}

Copyright for this article is retained by the author(s), with first publication rights granted to the journal.

This is an open-access article distributed under the terms and conditions of the Creative Commons Attribution license (http://creativecommons.org/licenses/by/4.0/). 